Acta Theriologica 35(1-2): 165-169, 1990.

PL ISSN $0001-7051$

\title{
The reproductive cycle of Talpa occidentalis in the southeastern Iberian Peninsula
}

\author{
Rafael JIMÉNEZ, Miguel BURGOS, Antonio SÁNCHEZ \\ and Rafael DÍAZ DE LA GUARDIA
}

Jiménez R., Burgos M., Sánchez A. and Díaz de la Guardia R. 1990. The reproductive cycle of Talpa occidentalis in the southeastern Iberian Peninsula. Acta theriol. 35: 165-169.

The small Iberian mole Talpa occidentalis Cabrera, 1907, is sexually active during a period lasting from September to May. Both males and females reach seasonal maturity after the age of one year, and their reproductive organs undergo seasonal histological and functional fluctuations. During the period of sexual repose males have small testes in which the germinative epithelium of the seminiferous tubules is degenerated, so that they decrease in diameter and lack spermatozoa. Females show seasonal fluctuations in the size and degree of blood supply to the uterus, which contrasts with observations made by other authors in the Europaean mole Talpa europaea. The long breeding season in the population studied permit some females to give birth to several litters per year. Our findings support the hypothesis that a latitude-related gradient affects the duration of the reproductive season in all European moles.

Departamento de Biología Animal, Ecología y Genética. Facultad de Ciencias, Universidad de Granada, 18071 Granada, Spain

Key words: reproduction, Talpa occidentalis, Iberian Peninsula

\section{Introduction}

The mole Talpa occidentalis Cabrera, 1907, is distributed throughout most of the Iberian Peninsula (except in northeastern areas) from Cantabria (Santander) to the Catalonian coast, where T. europaea is found. Jiménez et al. (1984a, b) established clear karyotypic differences between $T$. occidentalis and $T$. caeca, a similar species which some have considered present in the Iberian Peninsula.

The reproductive cycle of the common mole Talpa europaea has been widely studied in several European populations (Stein 1950, Grulich 1967 a, b, Lopez-Fuster et al. 1988, among others). Although several cytogenetic studies in T. occidentalis have investigated the meiotic behavior of the sex chromosomes and polymeiosis (Jiménez et al. 1984a, b) and sex reversal in XX males and intersexes (Jiménez et al. 1988), no data on the reproductive cycle of this species have been published.

In this study we describe the sexual cycle of $T$. occidentalis from the southeastern Iberian Peninsula and compare it with other Talpa populations from the rest of Europe in terms of a possible latitude-related gradient in the length of the period of sexual activity.

\section{Material and methods}

The material consisted of 137 moles, of which 78 were normal XY males and 59 had an external female phenotype, although in 32 individuals, ovaries were replaced by evident ovotestes. The sexual characteristics 
of these individuals (uterus, vulva and mammary gland development) were however very similar to those of normal females, so that in this study we made no distinction between the two kinds of XX individusls. These animals were trapped live in the farmlands on the alluvial plain near Granada (Spain) between 1985 and 1988. For males, sexual activity was estimated on the basis of testis weight (average of both testes), diameter of seminiferous tubules and histological development of testes (from conventional histological preparations), sperm production level (based on sperm counts in epididymes as described previously by Jiménez et al. (1988) and relative age estimated by the degree of tooth-wear Jiménez et al. (1988). For femaes, the condition of the vulva, the degree of development and blood supply to the uterus, the presence or absence of embryos and the development of the mammary glands were the criteria used to estimate sexual activty. Age was estimated as in males. We distinguished three age-groups: sub-adults, adults and aged animals.

\section{Results and discussion}

Figure 1 shows male sexual activity throughout the year. Wide variations were observed in testis weight (TW), diameter of seminiferous tubules (DST) and epididymal sperm contents (ESC) for young (sub-adult) and adult males. Sub-adult males, caught from February to August, were sterile and showed very low testis weights. This situation remained unchanged until August-September, when testes grew rapidly and spermatogenesis started. These individuals were considered fertile young adults.

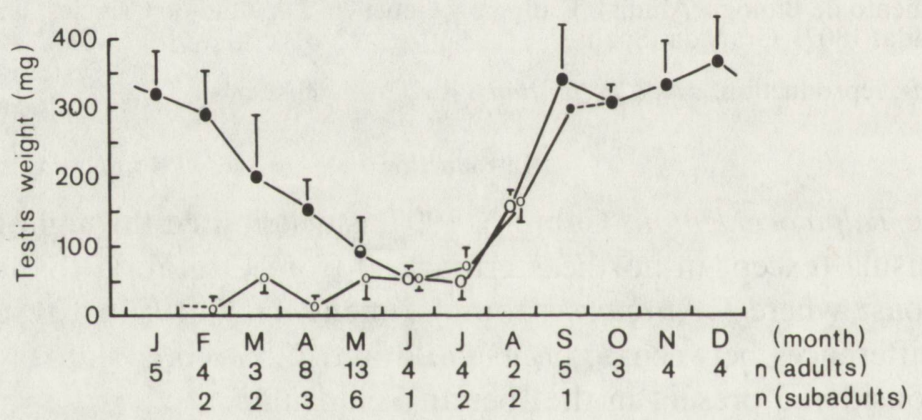

Fig. 1. Variation in testis weight throughout the year in sub-adult (small circles) and adult (large circles) males of Talpa occidentalis. In both cases, empty circles represent those months in which all males are azoospermic, half-full circles indicates those months in which both fertile and sterile males coexist and black circles represent those month in which all males are fertile. Vertical bars indicate standard deviations.

Adult males showed sexual activity from September to May, and were inactive the rest of the year. In the period from September to February all three parameters of sexual activity reached highest values $(310 \mathrm{mg}<\mathrm{TW}<470 \mathrm{mg}$, DST $>140 \mu \mathrm{m}$ and $\mathrm{ESC}>4.2 \times 10^{7}$ ).

From May to August all males became sterile (Fig. 1). During sexual repose, testicular weight fell sharply, reaching lowest values in June-July $(20 \mathrm{mg}<\mathrm{TW}<50$ $\mathrm{mg}$ ). This was followed by rapid development during August-September, when the testes became active once again, completing the cycle.

Sub-adult males thus do not reach sexual maturity until the age of approximately 

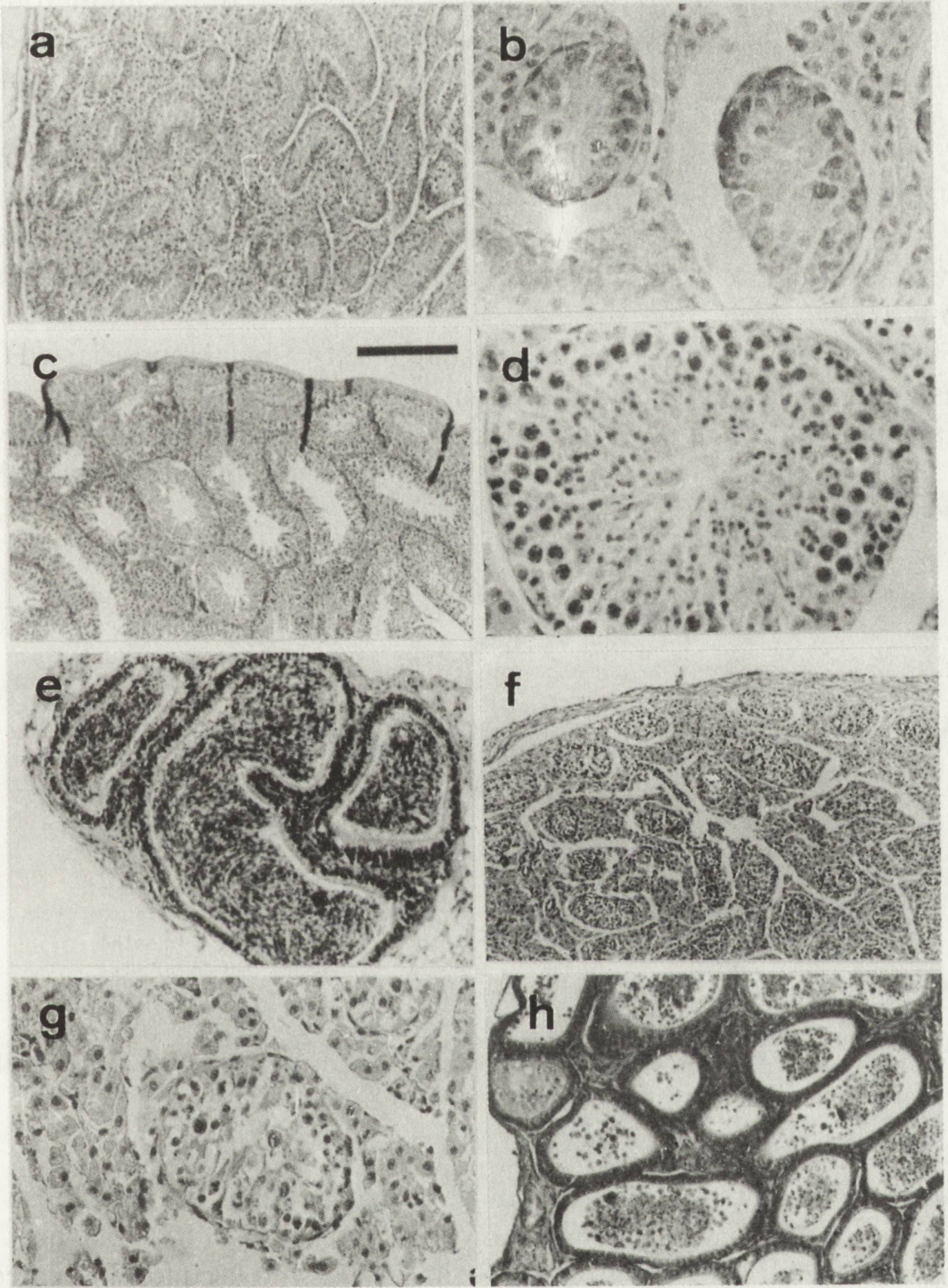

Fig. 2. Histological analysis of the testes of Talpa occidentalis in different stages of the sexual cycle. (a) and (b), juvenile testis showing thin seminiferous tubules and extensive interstitial matrix of Leyding cells; (c) and (d), adult male during a period of sexual activity in which seminiferous tubules have increased in diameter and show a well-developed germinative epithelium; (e), epididymis from the same testis as in (c) and (d), showing abundant spermatozoa; ( $\mathrm{f}$ ) and (g), testis from a sexually inactive male in which degeneration of the germinative epithelium is clearly visible, as well as a decrease in diameter of the seminiferous tubules; (h), epididymis from the same testis, lacking spermatozoa but showing abundant cell debris. Bar represent $200 \mu \mathrm{m}$ in (a), (d), and (g); $100 \mu \mathrm{m}$ in (f); $50 \mu \mathrm{m}$ in (b), (c), (e) and (h). 
one year. Before this time, their testes show typically juvenile characteristics (Fig. 2a and b): a dense matrix of interstitial Leydig with thin seminiferous tubules.

In active testes the seminiferous tubules were well developed with evident lumina and a thick germinative epithelium (Fig. 2c). Several cell layers were seen in different stages of spermatogenesis (Fig. 2d). The epididymis showed abundant spermatozoa (Fig. 2e). Sexually inactive testes from adult males showed a reduced seminiferous tubule diameter (Fig. 2f) and degeneration of the germinative epithelium, so that abundant cell debris was sloughed off into the lumen (Fig. $2 \mathrm{~g}$ ). Consequently the epididymis lacked spermatozoa and appeared to be filled with products of germinative epithelium degeneration (Fig. 2h).

The cycle of activity in uteri paralleled that in tests. Sexual repose lasted from May to August, activity taking place throughout the rest of the year. Changes in uterine development and blood supply clearly reflected this cycle (Fig. 3). Adult individuals of Talpa occidentalis showed seasonal fluctuations in size and blood supply to the uterus.

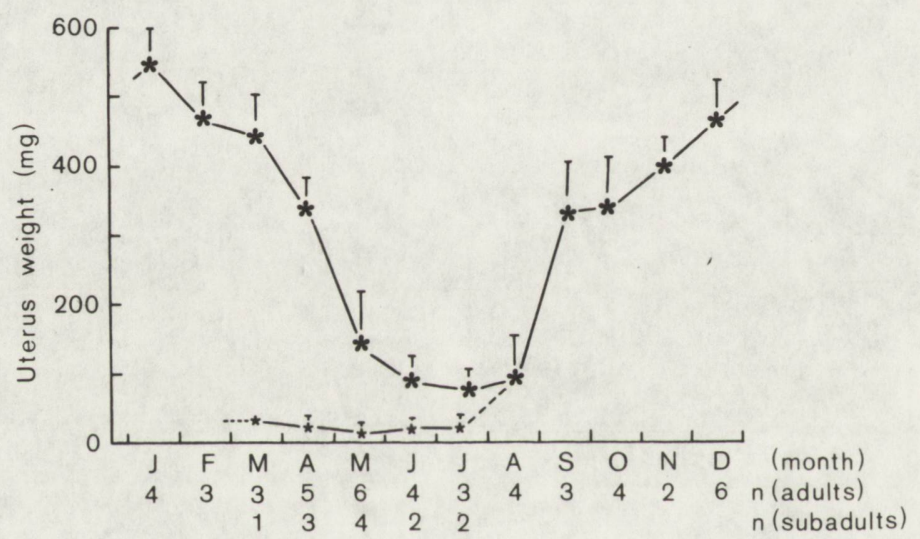

Fig. 3. Variation in uterus weight throughout the year in sub-adult (small stars) and adult (large stars) females of Talpa occidentalis. Vertical bars indicate standard deviations.

Lowest average weight was recorded during the period of sexual repose (25-100 $\mathrm{mg})$ and highest average weight coincided with sexual activity $(100-550 \mathrm{mg})$. This was surprising, in view of the observations of Stein (1950), who used term "dilated uterus" to distinguish mature from immature females of Talpa europaea without, however, indicating whether they were sexually active or not. According to this author, when the female reaches sexual maturity, the uterus becomes dilated and remains so for the rest of the animal's life. Our results contradict those of Stein (1950) particularly since $T$. europaea and $T$. occidentalis are closely related species in which such a marked physiological difference would not be expected.

Pregnant females were found from October to April $(n=10)$, while suckling females were caught between November and May. Hence in this population of $T$. 
occidentalis, the breeding season probably lasts from September to May, while sexual repose takes place during the summer (June-August). This is a very long period of sexual activity (nearly nine months) in comparison with other European populations of the genus Talpa. The breeding season differs in duration among different populations of T. europaea, being very short (two to three months) in Northern and Central Europe (Grulich 1967b) and significantly longer (five to six months) in the Northeast of the Iberian Peninsula (Vericad 1970, López-Fuster et al. 1988). Although these studies involved different species, the results suggest that a latitude-related gradient may affect the duration of the breeding season, making it shorter in northern populations and gradually longer in populations which live closer to the equator. As suggested by López-Fuster et al. (1988), these differences may be related to different climatic conditions in the north and south of Europe.

\section{References}

Grulich I. 1967a. Zur Biologie des Maulwurfs, Talpa europaea L., in der Periode seiner Selbstandigen Lebensweise. Zool. Listy 16: 41-59. - Grulich I. 1967b. Die variabilitat der Taxonomischer Merkmale des Maulwurfs (Talpa europaea L., Insectivora) im Zusammenhang mit Alter und Geschlecht. Zool. Listy 16: 125-144. - Jiménez R., Burgos M. and Díaz de la Guardia R. 1984a. Karyotype and chromosome banding in the mole (Talpa occidentalis) from the Southeast of the Iberian Peninsula. Implications on its taxonomic position. Caryologia 37: 253 - 258. - Jiménez R., Burgos M. and Díaz de la Guardia R. 1984b. Meiotic behaviour of sex chromosomes and polymeiosis in three species of insectivores. Genetics 65 : 187-192. - Jiménez R., Burgos M. and Díaz de la Guardia R. 1988. Sex reversal in a wild population of Talpa occidentalis (Insectivora, Mammalia). Genet. Res. 52: 135 140. — López-Fuster M. J., Gosálbez J. and Lluch S. 1988. Characteristics of the reproductive cycle of the mole, Talpa europaea, in the Northeast of the Iberian Peninsula. Acta theriol. 33: 131-137. - Stein G. H. W. 1950. Zur Biologie des Maulwurfs, Talpa europaea L. Bonn. Zool. Beitr. 2: 79-116. - Vericad J. R. 1970. Estudio faunistico y biológico de los mamiferos montaraces del Pirineo. Publ. Cent. Pirenaico Biol. Exp. 4: 1-231. Jaca.

Received 26 May 1989, accepted 14 August 1989. 